\title{
A RELIGIÁO FORA DA IGREJA: COMENTÁRIO AO TEXTO DE PAULA MONTERO
}

Emerson Giumbelli ${ }^{1}$

Resumo: O texto tece breves comentários ao artigo de Paula Montero, "Religião cívica, religiấo civil, religiâo pública: continuidades e descontinuidades". O objetivo é, junto com a autora, pensar sobre conceitos aos quais recorremos e com os quais nos deparamos em nossas pesquisas. Tomando os mesmos conceitos propostos por Montero (religião cívica, religião civil e religiâo pública), o foco recai sobre as questóes que cada um deles e o conjunto por eles formado permitem endereçar. A mais importante delas é a da definição social do religioso.

Palavras-chave: Definição Social de Religião; Religião e Espaço Público; Campo Religioso Brasileiro.

Abstract: The text presents brief comments on the article by Paula Montero, "Religião cívica, religião civil, religião pública: continuidades e descontinuidades". The objective is to follow Montero in thinking about the concepts to which, as researchers, we adopt and with which we come across in research. Taking the same concepts chosen by Montero (civil religion, civic religion, and public religion), the focus is on the issues that each one of them and all the three allow to address. The most important one is the social definition of religion.

Keywords: Social Definition of Religion; Religion and Public Space; Brazilian Religious Field.

Paula Montero destaca-se entre as intelectuais que mais têm contribuído para os debates recentes sobre o papel das religiôes na vida pública. Depois de seus estudos acerca das relaçóes da Igreja Católica com os meios de comunicaçáo, das relaçóes entre religião e cura na umbanda, das vicissitudes da

1 Professor Associado da Universidade Federal do Rio Grande do Sul, atuando no Departamento de Antropologia e no Programa de Pós-Graduação em Antropologia Social. Contato: emerson.giumbelli@yahoo.com.br 
categoria cultura em discursos religiosos e empreendimentos missionários, ela vem publicando textos seminais para a discussão de temas como pluralismo religioso, tolerância e a presença pública das religióes (Montero, 2013, 2015, 2016, 2017, para citar apenas alguns dos mais recentes). Embora seu campo de pesquisa esteja focado no Brasil, seus diálogos intelectuais vão muito além, como demonstra o texto ora em debate.

O tema central desse texto são as relaçôes entre religião e política. A pergunta que a autora se faz é sobre os limites e os alcances de nossa reflexão quando orientadas por três noçóes: religião cívica, religiáo civil e religião pública. Depois de sistematizar criticamente algumas referências que remetem a cada uma dessas três noçóes, Montero vale-se do contraponto entre elas para explorar uma série de questóes, declarando ao final sua preferência pela noção de religião pública.

Os comentários a seguir foram formulados naquilo que creio ser o mesmo ânimo que orienta o texto em debate. Ou seja, um exercício que nos estimula a pensar sobre conceitos aos quais recorremos e com os quais nos deparamos ao fazer nossas pesquisas. $\mathrm{O}$ que me parece mais interessante destacar, no caso das três noçóes selecionadas por Montero, não é a vantagem de um sobre outro, mas as questóes e dimensóes que cada um deles e o conjunto por eles formado permitem endereçar. Tomo como tácito o reconhecimento de que esse conjunto é, em alguma medida, arbitrário - por exemplo, por que não somar a esses conceitos o de religião política, como o faz Ranquetat Jr. (2016, p. 42-47)? -, condição que não o torna menos interessante ou pertinente. Além disso, e mais importante, considero um conjunto provisório, uma vez que apenas provoca, sem resolver, uma questão crucial, como a própria Montero admite: a da definição do religioso. Mas, vamos por partes.

O primeiro passo em meu exercício - e acompanho a autora nisso - é situar os conceitos propostos. A noção de religião cívica tal como é utilizada e elaborada pelo coletivo de autores recenseados por Montero remete ao quadro da cristandade medieval. Nesse quadro, ao mesmo tempo em que havia uma diferenciação de funçóes e autoridades, a centralidade e a relevância dos assuntos relativos ao panteáo e aos rituais cristáos eram claras. 
Como nos lembra a autora, a ideia de religiáo cívica evoca "a preocupação [...] com as questóes religiosas e o reconhecimento de sua importância para o interesse coletivo". Esse é portanto o quadro histórico, social e cultural que confere inteligibilidade à ideia de religiâo cívica. ${ }^{2}$

Já o conceito de religião civil, na formulação desenvolvida pelo sociólogo estadunidense Robert Bellah, remete a um quadro completamente distinto. Está em sintonia com uma concepção protestante de religiáo, que privilegia a crença em detrimento das práticas (Meyer; Houtman, 2012). A proposição de J. J. Rousseau (1973) - que não é meramente conceitual, mas política (aliás, dimensão que Montero aponta não estar ausente das preocupaçóes de Bellah) - já ia nessa direção, uma vez que para o filósofo do séc. XVIII a religiáo civil resumia-se a um conjunto de "dogmas", em que se destacava "a santidade do contrato social e das leis" e a proibiçáo à "intolerância". Embora Bellah considere a importância de rituais, é por serem estes a ocasiáo em que se expressa algo que, como Montero demonstra, equivale a uma fé - ou seja, a crença em seu estado mais abstrato. Nada mais distante, por exemplo, da sensibilidade católica em seu apreço pela dimensão sacramental da religião.

No caso da noção de religião pública, diria que os limites, mais do que históricos, são teóricos. Montero levanta várias questôes pertinentes sobre o trabalho de José Casanova e toca em um possível catolicocentrismo da perspectiva do sociólogo espanhol, salientando que seria preciso reconhecer que a ideia de religião pública não pode ser operacionalizada da mesma maneira em realidades que seguem modelos distintos (católicos ou protestantes). Contudo, o ponto que destaco está relacionado com as insuficiências dessa noçáo de religião pública para dar conta de processos que envolvem a presença pública das religióes. Essa crítica servirá para que eu empreenda o segundo passo de meu exercício.

2 Para uma discussão sobre essas configurações em cidades brasileiras da época colonial e imperial, ver Santos (2005). 
Quando Casanova (1994) escreve seu livro sobre religiōes públicas, sua preocupação está em chamar atenção para processos de desprivatização. Para tanto, ele analisa quatro contextos nacionais e a forma como as igrejas, sobretudo a instituição católica, tiveram um papel significativo em transformaçôes políticas. Ora, a categoria "desprivatização" mostra-se pouco adequada para se aplicar a situaçóes nas quais a religião não sofreu uma privatização prévia, ao menos no sentido e com o peso que isso ocorreu em quadros muito específicos. Outro problema da elaboração de Casanova é que ele pretende manter a validade de um dos pontos da tese da secularização, a saber, o da distinção entre esferas sociais. Como Montero afirma, ecoando a crítica de Asad, o próprio Casanova, em elaboração mais recente, confessa não ser fácil ter certeza sobre "onde começa o religioso e onde começa o secular".

Portanto, se mantemos o vínculo entre o conceito de religiấo pública e esses dois pontos - desprivatizaçáo e religião como esfera diferenciada -, suas insuficiências, a meu ver, são manifestas. Concordo que o conceito pode ser útil se o tomamos como passo para a construção de recursos analíticos mais adequados para captar as formas de presença das religiôes nas sociedades contemporâneas. É nessa direção que podemos retomar cada um dos três conceitos reunidos por Montero para extrair deles questóes interessantes para tratar dessas formas de presença. Proponho, assim, que os tratemos como formulaçôes provisórias que podem gerar elaboraçôes mais pertinentes, se a intenção é dar conta de quadros históricos ou teóricos distintos daqueles a que estão presos. Se o primeiro passo consistiu em situar esses conceitos, o segundo busca alterá-los.

Montero nos dá uma pista valiosa quando enfatiza que o conceito de religião cívica remete à cidade. $\mathrm{Na}$ cristandade, essa conexão, como vimos, está relacionada com uma configuração na qual o "culto divino" é "considerado um serviço público, quase tão vital quanto o abastecimento e a defesa”. O interesse sobre o "culto divino" precisa ser atualizado quando vivemos em sociedades - e cidades - nas quais deixa de existir o consenso de que representa uma coisa "vital". Em outros termos: o fato de que a religião deixa de ser central não elimina a questão sobre como gerir as instituiçóes 
que se dedicam ao "culto divino". Tais operaçôes envolvem uma série de mediaçōes, como por exemplo os estatutos jurídicos ("associaçôes", "patrimônio", etc.) que se atribuem às instituiçóes religiosas e o que se exige, ou não, delas para ocupar um espaço nas cidades. Essas mediações envolvem dispositivos e agentes de naturezas diversas, incluindo neles os que assumem a identidade de "religióes". ${ }^{3}$

O conceito de religiáo civil, por sua vez, retomando os termos de Montero, remete à nação. Rousseau, quando o elaborou, foi extremamente perspicaz ao perceber que os modernos sistemas de representação política tinham que se preocupar com sua legitimação. Como conferir "santidade" às normas que nossos representantes confeccionam? Essa é a mesma questão que subjaz às formulaçôes de Bellah, cunhadas em linguagem protestante. Mas não precisamos nos restringir ao protestantismo para perceber a inexorabilidade dos processos de legitimação. A questáo é saber que papel será reservado à "religião" nesses processos, questão que alguns pretendem resolver com a afirmação da laicidade como princípio de organização social. O problema, contudo, é mais complexo, pois o que está em disputa é a própria definição do que seja religiáo quando se trata de definir a natureza das leis. Por exemplo: há algo de religioso nos direitos humanos? ${ }^{3}$

Por fim, o conceito de religião pública remeteria à sociedade civil. Mas, se é possível continuar em acordo com Montero, deve-se acrescentar que a própria ideia de sociedade civil é uma construção histórica. Não apenas como categoria, mas também como realidade. Isso coloca em jogo as formas pelas quais se elabora e se compreende a relação entre "religiáo" e "sociedade civil". Longe de ser apenas uma questáo abstrata, ela remete aos modos concretos pelos quais as religióes atuam na sociedade. Estamos falando de

3 Para uma análise de como propostas legislativas, na maior parte de iniciativa de parlamentares religiosos, incidem sobre as condiçóes das igrejas nas cidades, ver Giumbelli e Scola (2016).

4 Ver o trabalho de Steil e Toniol (2012) sobre a relação entre Igreja Católica e direitos humanos no Brasil. 
atores religiosos que pretendem influenciar rumos históricos estipulados por grandes narrativas, que buscam ter representantes nos parlamentos, ou que intervêm na organização comunitária em nível local? Os atores não religiosos - e essa identidade é frequentemente relativa - encaram essas atuaçôes como legítimas ou espúrias, consideram-nas como oportunidades de parcerias ou mobilizaçóes adversárias, relevam ou destacam as diferenças que podem existir por conta de visóes de mundo?5

Percebe-se que tratar os conceitos de religião cívica, religião civil e religião pública como provisórios não significa simplesmente descartá-los; sua utilidade está em nos fazer alterar as questôes que acompanharam a sua formulação. Sugeri alguns exemplos nos parágrafos anteriores, mantendo propositalmente o formato de questóes. Sublinho que nos três casos o tema do pluralismo é algo fundamental. Em contextos nos quais a diversidade religiosa está estabelecida, é importante perguntar se e como isso é reconhecido na sociedade. Essa pergunta pode ser elaborada em vários âmbitos: no plano da gestão dos grupos religiosos, no das referências religiosas que eventualmente cumprem funções de legitimação, no das formas de atuação de agentes religiosos. Percebe-se entâo como os desdobramentos propiciados pelos três conceitos ganham a chance de interpelar o tema do pluralismo foco, aliás, de outros textos de Montero (2006, 2009).

Em conclusão, vale reforçar um ponto que talvez não tenha ficado suficientemente explícito até aqui. A alteração que produz questóes que se vinculam e se descolam dos três conceitos discutidos no texto de Montero demanda que tragamos o tema da definição do religioso para o centro da discussão. Nesse sentido, concordo com a observação da autora sobre "como é difícil definir e/ou descrever a religião como uma entidade empírica quando o fenômeno que se quer observar está 'fora da Igreja'. Com efeito, uma das limitações comum a essas três abordagens é ter deixado como um impensado o termo religião". Creio que um dos caminhos por onde podemos avançar nossos debates sobre as formas de presença pública da religião é

5 Ver, entre outros, o trabalho de Joanildo Burity (2015). 
contemplando os complexos processos envolvidos em definiçôes sociais de religião. Algo que, em vários textos, chamei de "regulação do religioso" (Giumbelli, 2014, 2016).

De fato, fora da Igreja existe religião. Mas para que isso possa ser reconhecido ainda como tal é preciso que se adeque a alguma definição de "religiáo" socialmente processada. Gerir o "religioso", ter legitimação "religiosa" e constatar uma atuação "religiosa" dependem dessas definiçóes. Se conceitos como religião cívica, religião civil e religião pública nos ajudam a compreender tais dinâmicas, vale a pena discuti-los. Ademais, eles são a prova de que a categoria "religião" presta-se a metaforizações que servem para observamos processos amplos, que envolvem outros aspectos e agentes da sociedade. Diz-se às vezes que a política é (como) uma religião. Nesse caso, também usamos a religião para ir além das igrejas.

\section{REFERÊNCIAS}

BURITY, Joanildo. A cena da religião pública: contingência, dispersão e dinâmica relacional. Novos Estudos CEBRAP, n. 102, p. 89-105, jul. 2015. Casanova, José. Public Religions in the Modern World. Chicago: University of Chicago Press, 1994.

GIUMBELLI, Emerson. O problema do secularismo e da regulação do religioso: uma perspectiva antropológica. In: . Simbolos Religiosos em Controvérsias. São Paulo: Terceiro Nome, 2014. p. 209-230.

- Regulação do religioso: discussões conceituais e panorama da situação em quatro países latino-americanos. Ciencias Sociales y Religión/ Ciências Sociais e Religiāo, Porto Alegre, v. 18, n. 25, p. 14-37, dez. 2016.

GIUMBELLI, Emerson; SCOLA, Jorge. Definindo a liberdade religiosa: projetos acerca do estatuto de instituiçóes religiosas no Congresso Nacional brasileiro. In: VITAL DA CUNHA, Christina; ARAÚJO, Melvina (Org.). Religiāo e Conflito. Curitiba: Prismas, 2016. p. 25-44. 
MEYER, Birgit; HOUTMAN, Dick. Introduction. In: MEYER, Birgit; HOUTMAN, Dick (Org.). Things: Religion and the Question of Materiality. New York: Fordham University Press, 2012. p. 1-23.

MONTERO, Paula (Org.). Religiāo e controvérsias públicas: experiências, práticas sociais e discursos. São Paulo: Terceiro Nome; Unicamp, 2015.

. Religiâo, laicidade e secularismo: um debate contemporâneo à luz do caso brasileiro. Cultura y Religión, Iquique, v. 7, n. 2, p. 13-31, jun./ dic. 2013.

. Religiáo, pluralismo e esfera pública no Brasil. Novos Estudos CEBRAP, São Paulo, n. 74, p. 47-65, mar. 2006.

. "Religiōes Públicas" ou Religiáo no Espaço Público? Para uma crítica ao conceito de campo religioso em Pierre Bourdieu. Religião \& Sociedade, Rio de Janeiro, v. 36, n. 1, p. 128-150, 2016.

. Secularização e espaço público: a reinvenção do pluralismo religioso no Brasil. Etnográfica, Lisboa, v. 13, n. 1, p. 7-16, 2009.

. The "culture of justification" in the production of public religiosities in Brazil. In: MAPRIL, José et al. (Org.). Secularisms in a postsecular age? Religiosities and Subjectivities in Comparative Perspective. Chicago: Palgrave, 2017. p. 207-229.

RANQUETAT JR., César. Laicidade à Brasileira: um Estudo sobre a Controvérsia em Torno da Presença de Símbolos Religiosos em Espaços Públicos. São Paulo: Paco Editorial, 2016.

ROUSSEAU, Jean-Jacques. O Contrato Social [1762]. In: Rousseau.

São Paulo: Abril Cultural, 1973. (Coleçấo Os Pensadores).

SANTOS, Beatriz Catão Cruz. O Corpo de Deus na América: a festa de Corpus Christi nas cidades da América Portuguesa - século XVIII. São Paulo: Annablume, 2005. 
STEIL, Carlos Alberto; TONIOL, Rodrigo. A trajetória dos Direitos Humanos na Igreja Católica no Brasil: do discurso político ao discurso moral. In: OLIVEIRA, Pedro A. Ribeiro de; MORI, Geraldo De (Org.). Mobilidade religiosa: linguagens, juventude, política. São Paulo: Paulinas, 2012. p. 75-98.

Recebido em: 30/01/2018

Aprovado em: 30/01/2018

Debates do NER, Porto Alegre, ano i9, N. 33, P. 8I-89, Jan./Jul. 20 i 8 